\title{
IMPLEMENTATION OF NATIONAL EDUCATION POLICY (NEP) 2020 OF INDIA: A PERSPECTIVE ON PEDAGOGY FROM BHAGWAD GITA
}

\author{
Gita Manishi Swami Gyananand Maharaj" \\ Markanday Ahuja ${ }^{2}$, \\ Amarjeet Kaur Malhotra ${ }^{3 i}$ \\ 1Patron, SGN Gita Study \& Research Centre, \\ Gurugram University, \\ Gurugram, India \\ 2Dr., Gurugram University, \\ Gurugram, India \\ 3Professor Dr. \& Dean, \\ Faculty of Commerce \& Management, \\ Gurugram University, \\ Gurugram, India
}

\begin{abstract}
:
Purpose: The axle of this study is to trace out the educational implications from Bhagwad Gita with specific reference to 'Pedagogy' aspect in the successful implementation of National Education Policy-2020 of India. Design/methodology/approach: This study uses qualitative approach and deploys a mix of desktop and Hermeneutics analysis to trace out the educational implications with specific reference to 'Pedagogy' aspect while seeking perspective from Bhagwad Gita. The national education policy had been studied in detail and tens of research papers on pedagogy aspect along with a deeper study of Bhagwad Gita were studied to seek a perspective on pedagogy aspect of NEP-2020. Findings: The study concludes that the philosophy of the Bhagavad Gita has great potential to address the some of the crucial aspects of NEP-2020 especially the Pedagogy, which in itself is the most crucial deciding factor in the successful implementation of the NEP-2020. Thus, the success in implementation of NEP-2020 will depend on many factors including the pedagogy used by teachers who have to actually implement the policy at the ground level. The study concludes that the NEP 2020 can be successfully implemented by drawing learning with respect to pedagogy from our ancient treatise Shrimad Bhagwat Gita, which still stands ahead of times. This implies that in order to achieve the objectives of the new education system as laid down by NEP-2020, it is imperative to pay special attention to the pedagogical aspect of teaching, which in turn can be adopted from Bhagwad Gita. Originality/value: This is the first study of its kind
\end{abstract}

${ }^{i}$ Correspondence: email akmalhotra23@gmail.com 
where a mix of desktop and Hermeneutics analysis has been used while drawing inferences and relevance from Bhagwad Gita on Pedagogy aspect of NEP-2020, which could become the basis for successful implementation of the same and also for future studies in this direction.

Keywords: Bhagwad Gita, National Education Policy 2020, teaching pedagogy, hermeneutics analysis, desktop analysis

\section{Introduction}

The last National Policy on Education was introduced in the year 1986, thus after a gap of 34 years the new education policy (NEP-2020) has been announced on July $29^{\text {th }} 2020$. The NEP-2020 targets to reduce the cash rich content to its core essentials, and make space for critical thinking, holistic, enquiry-based, discovery-based, discussion-based, and analysis-based learning. Thus, the focus of the new education policy is to develop individuals who are critical thinkers and logical in their discussions and who have choices to explore various stream and make their own informed decision about the stream they want to major in. Further focus of NEP-2020 is to prepare learners for gainful and fulfilling employment while developing them ethical, rational, compassionate, caring individuals with strong values and character.

The NEP-2020 seems to be very promising and targets to develop critical thinkers who are innovative and multidisciplinary in their approach. But, this agenda of NEP2020 cannot be achieved with the current teaching pedagogy used in primary, secondary and higher education system of India, which targets to produce 'babus' as was intentionally envisioned and designed by Macaulay. The exiting literature suggests that the pedagogy is of utmost importance in achieving the objectives of any program. Webster's dictionary defines pedagogy as "the science of teaching". Now, there are many tools in teaching pedagogy used by educators in different steams and in different institutions. Paolini (2015) in his study found that the most impactful tool found in teaching pedagogy is use of thought-provoking curricula, interaction with students, being available and approachable, using differential instruction, addressing relevant material and developing structured courses that enable them to facilitate information and empower students which requires that teachers be prepared and well-versed in their subjects, design courses that reflect standards, and clearly communicate course content and expectations. It stimulates students' interest via discussion, experiential and actionoriented activities, and group work.

An educator's competency, knowledge, motivation, commitment and zest for learning has a very important role in fulfilling the academic accomplishments of students. Costa et.al (2015) show that students are more influenced by the competencies of teacher resulting in student interaction and learning performance positively and significantly which further influence students' academic accomplishment. Also study emphasis to understand the importance of communication, in the context of the classroom, and of the 
students' learning involvement in the academic activities. Using games and/or simulations in teaching is expected to have strong impact on developing cognitive quotient of learners. Vlachopoulos et al. (2017) also observed in their study that games and simulations have positive impact on learning goals, which is an important part of pedagogy only. As Barber \& Mourshed (2007) also infer that 'the quality of education system cannot surpass the quality of its teachers', it implies that for improvisation in the education system it is required to have trained teaching staff with respect to technological cognizance and awareness. Whelan (2009) in his study infer that for improving effectiveness in education it is required to have need based program of study to ensure that the curricula are relevant and contain enough flexibility to accommodate different learners and different social and economic needs. As observed in the study by Vlachopoulos et al. (2017) that the critical thinking should be complementary to teaching, which can be brought in through simulations and games as simulations and games bring insights into the topic of discussion. Susan (2007) lays whole emphasis on the skill of the teacher to ensure a better learning arrangement. This establishes the need for training of educators on pedagogical aspects and the same was concluded by Vippu et al. (2019) when they highlighted the need for pedagogical training of teachers to ensure quality education.

Thus, it is very clear from the above discussion that the pedagogy and assessment methods have strong impact on the learning outcomes of learners. Thus, the very objectives of NEP-2020 to develop innovative and critical thinkers cannot be achieved by using exiting one-way non-participative teaching and 'eat and vomit' assessment methods. Panditrao and Panditrao (2020) also say "by corollary and same logic, the presentday problems, especially related to the education and implementation of policies related with it cannot be solved using the older/erstwhile policies". Minbayeya et al. (2017) in their study on pedagogy of the twenty-first century conferred that changes in the pedagogy of teaching is entirely associated with change in ideology and the execution of education reforms depends entirely on the teacher which highly influences the students resulting in an active and competent personality.

However, the need to underline the duties of a teacher towards the students and the teaching learning process was felt much before which can be traced out in the great philosophical text, the Bhagavad Gita. Sahni N. and Rao S. K. (2017) argue in their paper that "when we examine from an educational perspective, the verses of the Bhagavad Gita depicts the duties of an ideal teacher as performed by Krishna to guide his student Arjuna who seeks for his help and guidance in overcoming the deviation of mind and maintain focus toward the duties that are expected of him". Shrimad Bhagwad Gita is the most imperative scripture available in the history of mankind, which guides the philosophy of living by answering all questions with rationale and logic which mankind face in the pursuit of life. It advocates the path of Karma or practice and its teachings are universal and transcendent.

This propels researchers to study the pedagogical implications from Bhagwad Gita into successful implementation of NEP-2020, which could be generalized to a large extent, hence this study. The next section of the paper reviews relevant literature and the 
third section talks about the motivation for the study. The fourth section frames objectives for the study. The next section, section five discusses research method used in the study and section six addresses the adoption of pedagogical learning from Bhagwad Gita into successful implementation NEP-2020 and finally the conclusion has been underlined in section seven.

\section{Review of Literature}

From, educators' point of view, the NEP-2020 aims to lay down common standards of teaching through the National Professional Standards for Teachers (NPST). Thus, brings the need of intense training of educators at all levels. Teachers needed to be trained for in a way that they are open to adopt new methods of teaching pedagogies and assessments. That is where the need to learn from Bagwad Gita comes in. Singh S. (2016) says that Bhagavad Gita is such a wonderful treatise on human development that it has drawn the considerable attention and interest of numerous scholars from almost all walks of life all over the world.

Sahni N. and Rao S. K. (2017) describes Gita as "This text ascribes to the philosophical discourse between Krishna and the Great Pandava warrior Arjuna which took place at the Kurukshetra battlefield. The role played by Krishna in the Mahabharata war is not just being Arjuna's charioteer, but also a guide who urges Arjuna for to maintain his righteous disposition and justful thoughts".

Mudgil (2017) argues in her study that Bhagwad Gita teaches the lesson of assimilation, synthesis and co-ordination. She further says "The Bhagavad-Gita is not a religious scripture, because its intention is not to cater to just the religious side of our nature or a part of our expectation in life, but it caters to the whole of what we need, and what we are". That is why the Bhagwad Gita is looked at as a 'Book with all the Answers to Life' than merely as a holy book. This does not just contain messages of Krishna to Arjuna, which were relevant for those days but has the messages for eternity and has timeless significance even for all of us living in the most dynamic and challenging conditions. Mudgil (2017) concludes that the vagaries of life have no impact upon this message, because it arises from a source which transcends the transitions of life.

Singh S. (2016) in his article concluded that "analyzing the various layers of personality of the learner and addressing each aspect of the developing personality of the learner at the appropriate juncture, this approach based on the teachings of the Bhagavad Gita inspires the learner to see the reality for himself/ herself and makes him/ her capable of carving out his/ her own path to righteousness (Swadharma) according to the innate nature or Swabhava, thus leading to a journey in excellence for each movement of life as an offering to the presiding deity or the revealed divinity within each individual".

The Bhagwad Gita offers an excellent example of pedagogy the teacher being Krishna and the pupil being Arjuna. When Arjuna admits of his physical and mental frailty and incapacity to deal with the situation, poised between the two armies in the middle of the battlefield, he is feeling weak his body is trembling, his hair is standing on 
end, and the Gandiva is also slipping from his hands. He does not know what to do. He then surrenders to lord Krishna and seeks his help to guide him in his actions. Arjuna realizes his helplessness and surrenders himself completely to the Lord, seeking His guidance to get over the conflict of his mind. The Lord takes pity on him and proceeds to enlighten him by various means. In verse 2/7 Arjuna is stating "My very being is stricken with the weakness of sentimental pity. With my mind bewildered about my duty, I ask Thee. Tell me, for certain, which is better. I am thy pupil; teach me, who am seeking refuge in Thee." Which means, man cannot live without action and on the same lines there is a saying in the English language that says 'Actions speak louder than words'. This same idea has been emphasized upon by Emerson: "What you do is so loud that I can't hear what you say".

The Bhagavad Gita is a gospel for the whole world and is meant for the generality of mankind, which was shared over five thousand years ago by Lord Krishna to Arjuna. Singh S. (2016) says that the ideas expressed herein and the pathways indicated are very logical, scientific and relevant even in the most trying situations of life, what to talk of our day to day struggles of existence. Vermani S. (2018) goes a step further and says that the Bhagwad Gita is not a religion, nor does it profess to be a religion. It is a concept of the Universe, viz a viz and the role human beings should perform in it. She further says in her article that "Bhagwad Gita deals with the subject of what is happiness, how to remain happy even in the midst of challenging situations. Like we use Google maps (GPS) to reach a destination, if we have Gita Practising System (GPS) we will be able to reach the destination of happiness. Gita is like a road map of happiness". Thus, the very objective of NEP-2020 to develop individuals with strong values and character leading to a happy life is in complete concurrence with the philosophy of Bhagwad Gita, establishes rationale for this study.

\section{Motivation of the Study}

Education is the backbone of any society which has potentials to make individuals to stand on their own feet by enabling them to develop into critical thinkers, rationale human beings who are sensitive and emphatic to the surroundings while achieving gainful employment. Thus, education is for life and not for livelihood as the ultimate goal of education to teach art of living and gaining an employment is a residual outcome. All this can be achieved only if the educators are able to deliver in a way which helps learners achieve these traits and skills, which in turn is dependent on the pedagogy used by educators. Thus, the pedagogy has the most important role to play to ensure that the NEP-2020 achieves its objectives. This becomes the motivation for the study to review the implications of learning from Bhagwad Gita with respect to pedagogy aspect which can be used for successful implementation of NEP 2020. 


\subsection{Objectives of the Study}

The overall objective of the study is to review and seek 'Pedagogy' perspective form Bhagwad Gita in successful implementation of National Education Policy 2020, with the following sub-objectives:

1) To review the NEP-2020 from the pedagogical aspect of implementation using Desktop analysis.

2) To review content of Bhagwad Gita and draw inferences using Hermeneutics approach with respect to Pedagogy aspect of NEP-2020.

\section{Research Method}

A mix of desktop and hermeneutics analysis has been used for this study. Hermeneutics is the study of interpretation. This is an established tool to study a discipline, where the subject matter involves human beliefs, actions, intentions and demands interpretative approaches. There are many disciplines like jurisprudence, theology, especially studies on Bible, and medicine, as well as some of the human sciences, social sciences, wisdom studies, philosophical texts and humanities where hermeneutics is used to draw inferences. Grondin (1994) says that in such contexts, hermeneutics is sometimes used as a supporting study of the arts, methods, and foundations of research appropriate to a respective disciplinary subject matter. More recently, applied hermeneutics has been further developed as a research method for a number of disciplines (see, for example, Moules inter alia 2015). Since, Bhagwad Gita is universally accepted, a wonderful treatise on human development, thereby using hermeneutics analysis for this study is justifiable. The verses of Bhagwad Gita which the researchers understand are directly related to the pedagogy aspect of teaching are studied and interpreted using this tool. Further, a tens of research papers on pedagogy have been reviewed using desktop analysis.

Since the objectives of this study is to review and seek 'Pedagogy' perspective form Bhagwad Gita in successful implementation of National Education Policy 2020, thereby, it becomes imperative to underline objectives of the NEP-2020. Figure 1 depicts objective of NEP-2020 which have direct bearing on the pedagogy aspect. This model has been adopted from Malhotra \& Verma (2021). The next section will analyse relevant verses from Bhagwad Gita which affect elements of pedagogy as depicted in Figure 1. 


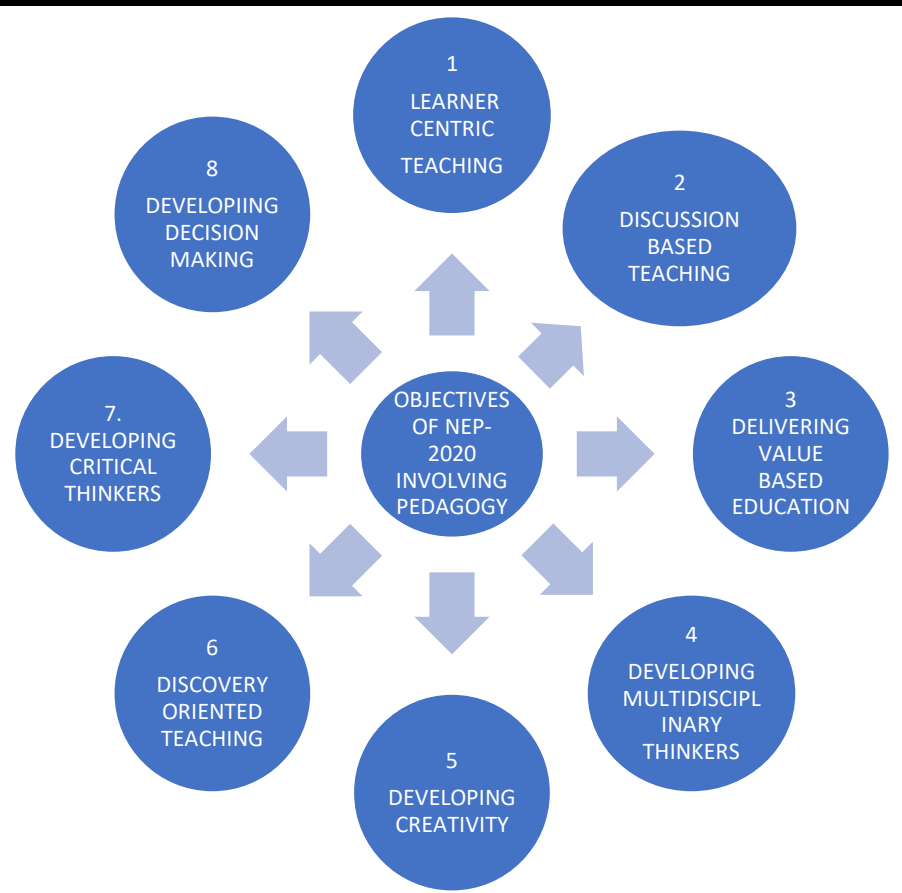

Figure 1: Depicting objectives of National Education policy 2020 involving Pedagogy (Source: Adopted from Malhotra A. K. \& Verma P. and Modified)

\section{NEP 2020 and Pedagogy Perspectives from Bhagwad Gita}

This section of the paper discusses relevant verses of Bhagwad Gita, which are perceived to have direct effect on pedagogy aspect of teaching as targeted in NEP-2020. All the elements of pedagogy depicted in the model by Malhotra \& Verma (2021) have been addressed one by one in the subsequent discussion using hermeneutics analysis. Authors form an argument that the objectives of NEP-2020 as shown in the above figure could be attained by reworking on the pedagogy.

Pedagogy is specific to individual educator and is something which evolves with experience, which is further dependent on the knowledge, awareness level, motivation level, available infrastructure and training and accountability of educators. Literature suggests that there are five major approaches to pedagogy: Constructivist, Collaborative, Integrative, Reflective and Inquiry Based Learning (2C-2I-1R). As the NEP-2020 focuses on developing individuals who are critical thinkers, innovators, multidisciplinary in their approach, this brings onus on to the educators to ensure that they conduct their classes in a way where learners are propelled to think and find answers themselves rather than spoon fed with solutions.

\subsection{Learner's Centric Teaching}

Bhagwad Gita has many verses where, Krishan as a teacher targets to clear doubts of his pupil, Arujna and plays best role of a teacher. Not only that, krishna addresses the current doubts but even possible future doubts likely to come to the mind of Arujna. Krishna as a teacher understand the importance of putting his pupil Arujuna in centre of his teaching and then clears away his doubts and gives the student an opportunity to think over and 
then act which otherwise would have led to loss of confidence towards his duties as a warrior. Below verses from Ch-2(55, 56 and 57) are in response to Arjuna's doubts (raised in verses 2.54) by his teacher Krishna. Further, verse 32 from chapter 9 of Bhagwad Gita shows that the Krishna, the teacher is open to all individual differences and suggests that an ideal teacher should be considerate and respectful to the individual needs of students beyond gender, caste, colour and creed, thus emphasising upon student's centric teaching.

Sthitaprajnasya kaa bhaashaa samaadhisthasya keshaval

Sthitadheeh kim prabhaasheta kimaaseeta vrajeta kim. II Bhagavad-Gita 2.54

śhrī bhagavān uvāchal

prajahāti yad̄̄ kāmān sarvān pārtha mano-gatān ।

àtmany-evātmanā tuṣhțạ̣ sthita-prajũas tadochyate || Bhagavad-Gita 2.55

duhkheșhv-anudvigna-manāh sukheșhu vigata-sprihaḥ I

vìta-rāga-bhaya-krodhah sthita-dhīr munir uchyate I| Bhagavad-Gita 2.56

yaḥ sarvatrānabhisnehas tat tat prāpya śhubhāśhubham |

nābhinandati na dveșhți tasya prajũa a pratișhțhitā | | Bhagavad-Gita 2.57

vișhayā vinivartante nirāhārasya dehinaḥ

mām hi pārtha vyapāśhritya ye 'pi syuh pāpa-yonayah I

striyo vaiśhyās tathā śhūdrās te 'pi yānti parām gatim || Bhagavad-Gita 9.32

\subsubsection{Perspective to Pedagogy Aspect of NEP-2020}

One of the pedagogical objectives of the NEP-2020 is to keep learners at the centre. Learner's centric teaching takes care of the individual learning needs of a student and ensure better results than a blanket approach. This perspective to teaching can be ascertained from above verses.

\subsection{Discussion Based Teaching}

In the verses of Ch-2(2) below, Krishna, the teacher questions Arjuna and asks for rationale(s) for showing such a sudden change in behaviour and decision of not participating in the war. Thus, this verse establishes the importance of discussion based teaching.

śhrī bhagavān uvācha I

kutastvā kaśhmalamidami viṣhame samupasthitam |

anārya-jușhțamaswargyam akīrti-karam arjuna || Bhagavad-Gita 2.2 
kachchid etach chhrutam pārtha tvayaikāgrena chetasā ।

kachchid ajñāna-sammohah pranașhțas te dhanañjaya | | Bhagavad-Gita 18.72

In the verses of Ch-18(72) above, Krishna probes into the capacity of Arjuna being vigilant and also ensures that his misconceptions are erased. Thus, this is established that the Bhagavad Gita brings out two kinds of situations in which an ideal teacher should pose questions to students. The first instance is where the student is provoked needed to justify his/her weird attitude while giving an opportunity to the student to keep his view point forward. The second one is where the students' understanding needs to be confirmed, for which a teacher needed to ask questions related to the concept/idea discussed, thus discussion based learning.

\subsubsection{Perspective to Pedagogy Aspect of NEP-2020}

The existing literature on pedagogy suggests that the learning after the open discussion is imbibed at much higher level than one sided passive delivery. Since, the very objective of NEP-2020 is to develop individuals who are able to take decisions thus the teaching pedagogy should be discussion participatory teaching. A teacher can probe questions during or after the concept has been introduced, which will bring better clarity and effective learning outcome.

\subsection{Delivering Value Based Education}

There are many verses in the Bhagwad Gita which emphasise upon developing the value system of students. Krishna says that one should never abandon one's intrinsic duty and all innate duties must be performed by all individuals without fearing for consequences while living up right with a strong value system. For example, verses of Ch-16 (1) Krishna describes first the divine qualities and then the demoniac. The same way a teacher is expected to help a student understand the difference between the two so that a student consciously adapts values of a good human being.

In verses CH-16 (2), Krishna emphasises upon such communication, which is conducive to the good of others and further focuses upon the qualities where one is free from anger, renunciation and follows tranquility, gentleness and acapalam while keeping compassionate to others. In verses 16.3, Krishna lays down further importance of vigour, forgiveness, fortitude, purity, freedom from malice, absence of haughtiness, thus emphasise upon the importance of keeping and living up to these values while acting under all conditions or in other words remaining 'Karamyogi' and dutifulness. Krishna brings out the power of values over the importance of knowledge. Any knowledge, which cannot be for the betterment of self and others is of no use. Thus, establishing the fact that life and actions without values and welfare of the mankind are of no use. Teachers must always encourage their students to perform their duties while never ignoring values. 
Abhayam sattwasamshuddhih jnaanayogavyavasthitih |

Daanam damashcha yajnashcha swaadhyaayastapa aarjavam | | Bhagavad-Gita 16.1

Ahimsaa satyamakrodhas tyaagah shaantirapaishunam I

Dayaa bhooteshvaloluptwam maardavam hreerachaapalam | | Bhagavad-Gita

Tejah kshamaa dhritih shauchamadroho naatimaanitaal

Bhavanti sampadam daiveem abhijaatasya bhaarata I Bhagavad-Gita 16.3

\title{
5.3.1 Perspective to Pedagogy Aspect of NEP-2020
}

Above discussion shows that teachers should constantly strive hard to inculcate values amongst their students, motivate the students to perform their respective duties by following the path of Karma i.e. Action. Since, NEP-2020 aspires to develop individuals with strong character and values, we can certainly draw inferences from the above discussion that Krishna had also put the same emphasise in Gita even years ago and the same still holds true.

\subsection{Developing Multidisciplinary Thinkers}

One of the objectives of the NEP-2020 is to develop critical thinkers who can visualise all aspects of a situation. In the verses of Ch-1(24) quoted below, Krishna performing his duty as a teacher, pursue Arjuna to both possible outcome of the war like two sides of the coin when Krishna finds Arjuna very confident about winning. He further pursues with Arjuna to not to get too much influenced by his immediate instincts but to plan and act emphasising upon the importance of critical thinking. Sahni \& Rao (2017) also say in their article "Lord Krishna places the chariot between the two armies as asked by Arjuna. This is done to make Arjuna get a better picture of the challenges he would face during the war by having a closer look of the warriors of the other army".

\author{
sañjaya uvācha I \\ evam ukto hrișhīkeśho guḍ̄keśhena bhārata I \\ senayor ubhayor madhye sthāpayitvā rathottamam | | Bhagavad-Gita 1.24
}

\subsubsection{Perspective to Pedagogy Aspect of NEP-2020}

One of the major duties of an ideal teacher is to make his pupils realize that the outcome of any effort is not certain and does not depend solely on one's potential ability but is also impacted by external factors on which an individual has little or no control. Thus, emphasising upon the critical abilities of students to consider all aspects of a given situation, thus establishing the importance of learning multi-disciplinary approach to solve a problem. This very perspective can also be learnt from Bhagwad Gita and can be implemented in the pedagogy for successful implementation of NEP-2020. 


\subsection{Developing Creativity}

The existing literature on creativity aspect of growth suggests that fearless, playful and free attitude on constant basis leads to creativity. Thus, if we wish to develop individuals as critical thinkers then it becomes important for a teacher to provide an environment to students where, they are fearless to experiment their ideas and learn through mistakes. There is no pressure that the failures or mistakes will be discounted in evaluating them. Such an aspect of teaching pedagogy will lead to developing critical thinkers. The verses Ch-2(31) below puts light on the same aspect, where Krishna says to Arjuna that apart from your prescribed duties, you should not hesitate in experimenting. Whereas the verses $\mathrm{Ch}$ 12(9) talks about joyful and stabilised mind focussing upon repeated practice to reach perfection, which means if the efforts of a person fail in one way, then the person should try other methods. This is what a teacher is expected to inculcate amongst students.

swa-dharmam api chāvekșhya na vikampitum arhasi I

dharmyāddhi yuddhāch chhreyo 'nyat kṣhatriyasya na vidyate I I Bhagavad-Gita 2.31

atha chittam samādhātum na śhaknoṣhi mayi sthiram I

abhyāsa-yogena tato mām ichchhāptuṁ dhanañjaya || Bhagavad-Gita 12.9

\subsubsection{Perspective to Pedagogy Aspect of NEP-2020}

NEP-2020 targets to instill creativity amongst students and for which having a fearless freedom to experiment with different ideas is a point of utmost importance. Thus, a fearless mind inhibits creativity and succeeds. Which in turns puts the responsibility on teachers to provide and environment of freedom, experimenting using various teaching tools, thus proving the pedagogical aspect of developing creativity, which was acknowledged by the Krishna decades ago in Bhagad Gita itself.

\subsection{Discovery Oriented Teaching}

In the verses of Ch-10(11) mentioned below, Krishna brings out an important aspect of ideal teacher, where a teacher is expected to propel students to discover light in the darkness. A student should be encouraged to discover the truth or solution by himself/herself. If a person focuses to discover solutions or even possible alternatives to any given situation by one self means the person is learning through participation. This is basically participatory teaching. Sahni \& Rao (2017) also say in their article that "Arjuna wished to see Krishna's divine form and asked to bestow him with this knowledge. As a result, Krishna the true master provides his student, Arjuna with the desired knowledge". Thus, the learning, which comes though discovery oriented teaching or in other words though participatory teaching is forever as this evokes interest of the learner and he/she is able to retain learning lifelong being part of the solution. 
teșhām evānukampārtham aham ajūāna-jam tamah ।

nāśhayāmyātma-bhāva-stho jūāna-dīpena bhāsvatā | | Bhagavad-Gita 10.11

sañjaya uvācha I

evam uktvā tato rājan mahā-yogeśhvaro harih I

darśhayām āsa pārthāya paramai் rūpam aiśhwaram || Bhagavad-Gita 11.9

\subsubsection{Perspective to Pedagogy Aspect of NEP-2020}

The NEP-2020 aspires to develop empowered individuals. Thus, it becomes imperative for a teacher to evoke the zest for discovery amongst students which can come through participatory teaching, where students are discovering possible alternatives on their own before reaching out to any solution. This very perspective of teaching pedagogy has also been put forth very lucidly by Krishna in Bhagwad Gita.

\subsection{Developing Critical Thinkers}

Critical thinking refers to the ability of a person to solve a problem using knowledge, facts, figures and data. Thus, this refers to the significance of judgement capability of individuals while dealing with any difficult situation. The NEP-2020 targets to develop critical thinkers, which in turns demands the possession of knowledge, practicing application of knowledge into action and having an ability to visualise all aspects of the problem. This in turns demands a huge responsibility on teachers. In the verses of Ch$2(32,33,34,35,36,37$ and 38) mentioned below, Krishna describes Arjuna's Duties as a warrior. Arjuna, though has knowledge about the duties expected from a Kshatriya, but was still not ready to fight against his loved ones. So, this brings out the significance of an ideal teacher to develop critical thinking amongst its students so that students could apply the knowledge into action as a critical thinker. In the verses of Ch-15(20) above, Krishna describes the rewards of grasping the knowledge imparted to Arjuna and also the duty of a student to study, self-reflect and practice. In the verses of Ch-2(18), Ch-3(30), Ch-4(42), and Ch-11(34) mentioned below, Krishna has guided Arjuna to the path he must choose and commands him to fight. By repeatedly asking him to fight, Krishna was guiding him to the path of critical thinking, which he was unsure of.

yadrichchhayā chopapannaṁ swarga-dvāram apāvritam |

sukhinaḥ kṣhatriyāh pārtha labhante yuddham ìdriśham || Bhagavad-Gita 2.32

atha chet tvam imam் dharmyam sangrāmam na karișhyasi I

tatah sva-dharmai் kìrtim cha hitvā pāpam avāpsyasi | | Bhagavad-Gita 2.33

akīrtim chāpi bhūtāni

kathayișhyanti te 'vyayām I

sambhāvitasya chākīrtir

maran̄ād atirichyate || Bhagavad-Gita 2.34 
bhayād raṇ̄ad uparatam mansyante tvām mahā-rathāh I

yeșhām cha tvaṁ bahu-mato bhūtvā yāsyasi lāghavam | | Bhagavad-Gita 2.35

avāchya-vādānśh cha bahūn vadiṣhyanti tavāhitāh ।

nindantastava sāmarthyam tato duhkhataram nu kim | | Bhagavad-Gita 2.36

hato vā prāpsyasi swargaṁ jitvā vā bhokșhyase mahīm I

tasmād uttiṣhțha kaunteya yuddhāya krita-niśhchayah || Bhagavad-Gita 2.37

sukha-duhkhe same kritvā lābhālābhau jayājayau ।

tato yuddhāya yujyasva naivami pāpam avāpsyasi | | Bhagavad-Gita 2.38

iti guhyatamaṁ śhāstram idam uktä̇ mayānagha I

etad buddhvā buddhimān syāt krita-krityaśh cha bhārata || Bhagavad-Gita 15.20

antavanta ime dehā nityasyoktāḥ śharīinịah ।

anāśhino 'prameyasya tasmād yudhyasva bhārata || Bhagavad-Gita 2.18

mayi sarvāṇi karmāṇi sannyasyādhyātma-chetasā ।

nirāśhīr nirmamo bhūtvā yudhyasva vigata-jvarah | | Bhagavad-Gita 3.30

tasmād ajūāna-sambhūtam hrit-stham jũānāsinātmanah ।

chhittvainaṁ sanśhayam் yogam ātiṣhțhottișhțha bhārata || Bhagavad-Gita 4.42

droṇam cha bhīṣhmam cha jayadratham cha

karnaim tathānyān api yodha-vīrān I

mayā hatāms tvam jahi mā vyathișhțhā

yudhyasva jetāsi raṇe sapatnān || Bhagavad-Gita 11.34

\subsubsection{Perspective to Pedagogy Aspect of NEP-2020}

At times, a student fails to consider all aspects of a situation, that is where the importance of a teacher comes in. A teacher, in this situation is expected to develop critical thinking among students so that they could use not only the theoretical knowledge of the subject but also all other related facts, figures, data perspectives of the problem before getting into actions. This, on the one hand, is a very demanding responsibility from a teacher and on the other hand requires teachers to be trained to use such a teaching pedagogy which translates into developing critical thinkers. This very complex aspect of teaching pedagogy can also be adopted from Bhagwad Gita as exhibited in above discussion.

\subsection{Developing Decision Making}

In the verses of Ch-18(63) mentioned above, Krishna says that now wisdom has been imparted by me to you Arjuna. Now it's the time for you to ponder over it and take the 
final decision accordingly. This is another duty of an ideal teacher where he/she imparts knowledge efficiently, puts forth the possibilities and gives the student enough time to contemplate and freedom to choose. This helps the student to take full charge of his decision and anticipating on all the possibilities helps him to look at the pros and cons of the path he wishes to choose. This also helps in boosting confidence in the student(s). Hence, it is very important to give the students freedom to choose.

iti te jūānam ākhyātam guhyād guhyataram mayā ।

vimriśhyaitad aśheșheṇa yathechchhasi tathā kuru | | Bhagavad-Gita 18.63

\subsubsection{Perspective to Pedagogy Aspect of NEP-2020}

The ultimate objective of any education policy should be to develop decision making among students and the NEP-2020 is not an exception to this most commonly accepted outcome. This very perspective of ultimate decision making by pupils has been very well brought out by Krishna in Bhagwad Gita where he finally leaves to Arjuna to decide to fight or not after he enabled him to see all possible outcomes and the importance of Karma in life. This very important aspect of teaching pedagogy can also be imbibed from Bhagead Gita in the successful implementation of NEP-2020.

\section{Conclusion}

The study concludes that the philosophy of the Bhagavad Gita has great potential to address the some of the crucial aspects of NEP-2020 especially the Pedagogy, which in itself is the most crucial deciding factor in the successful implementation of the NEP-2020 Thus, the success in implementation of NEP-2020 will depend on many factors including the pedagogy used by teachers who have to actually implement the policy at the ground level. The study concludes that the NEP 2020 can be successfully implemented by drawing learnings with respect to pedagogy from our ancient treatise Shrimad Bhagwat Gita, which still stands ahead of times. Consequently, it establishes the need for training of educators on pedagogical aspects while seeking a perspective from Bhagwad Gita and the same was concluded by Vippu et al. (2019) when they highlighted the need for pedagogical training of teachers to ensure quality education. This implies that in order to achieve the objectives of the new education system as laid down by NEP-2020, it is imperative to pay special attention to the pedagogical aspect of teaching, for which we can draw a perspective from Shrimad Bhagwad Gita. The study can be used as a basis for future studies to test individual aspect of pedagogy. The study is limited to pedagogy aspect of the NEP-2020 and there are many other factors which could be equally important in determining the success of NEP-2020 and have been kept out of the scope of this study and may become subject matter of study in future.

\section{Conflict of Interest Statement}

The authors declare no conflicts of interests. 


\section{About the Authors}

Swami Gyananand is an Indian saint who is known for his research on Bhagavad Gita and a famous Gita speaker. He is patron of SGN Gita Study \& Research Centre, Gurugram University and has interpreted the Gita and inspired many professionals globally. He is also a Hindu philosopher and a social worker. He is a founder of an organisation that follows Vaishnavism called "Shri Krishna Kripa Sewa Samiti". He has also founded another organization called "GIEO GITA" to promote Bhagavad Gita, so he is also known as Gita Manishi Swami Shri Gyananand ji Maharaj. He has done MA in Political Science, later he had become adherent student of his Gurudev Swami Gitanand, from where he attained philosophical interpretation Gita. He also founded GIEO GITA and under which he annually holds International Gita Mahotsav in Kurukshetra. A celebrated, renowned and respected Guru, Swami Gyananand is well liked for his extraordinary contribution with his desire to spread GITA and create a free world, Swami Ji has always bestowed his service to the world through his enlightened vision. Swami Ji aims in uniting the world through the medium of Gita, spirituality and with the roots of our ancient Vedic culture to create a divine, prosperous and a peaceful world to live in.

Dr. Markanday Ahuja is presently, serving as Vice Chancellor Gurugram University, Gurugram Haryana. He completed his MS and MBBS from Maharishi Dayanand University, Rohtak. Apart from professional qualification he holds masters in Business Administration and fellowship in Ophthalmology. While working as eye surgeon; he has credit of performing 2,50,000 surgeries and more than 29 lacs treated as outdoor patients. He is founder director of Shri Baba Mast Nath Group of Institutes that offers courses in Management, Engineering, Pharmaceutical Sciences, Dental Sciences, Nursing, Physiotherapy, Law, Ayurvedic Studies and college of Humanities. He is founder director of Shri. Mahatma Prabhu Ashrit Eye Hospital, Rohtak and an Eye bank, Baba Mast Nath Eye Hospital, Rohtak (Haryana). Dr. Markanday Ahuja sir holds life membership of All India Ophthalmological Society, Haryana Ophthalmological Society, Delhi Ophthalmological Society, Indian Medical Association and Indian Hospital Association, IMA Academy of Medical Specialties to name a few. He is credited with five hundred articles/Research papers in various National and International Journals and Magazines. He has also written books on Eye care and Ophthalmology that are published by various medical publishers. He is a prolific writer and is credited with writing books on Self-Management and character building. Dr Ahuja is actively working in social development sector for past few years. He is credited with holding awareness programs, seminars and workshops, conferences and rallies on health issues. He has conducted various Personality Development programmes; delivered more than 250 lectures on life management and skills in various colleges and universities.

Dr. Amarjeet Kaur has nearly three decades of experience in education and food industry. She is currently working as professor of Accounting, Dean, Faculty of Commerce \& Management and Director, Foreign Students Cell at Gururgram University, Gurugram, India. She is a Certified Management Accountant (CMA) from the Institute of Management Accountants (IMA), USA. She has dual master's degree: an MBA from 
The University of the West of the Scotland (UWS), UK and M.Com from MD University, India. She has taught at two prestigious Universities of USA viz., College of Business (AACSB Accredited) at Valparaiso University, Indiana and North Dakota State University, North Dakota. She has 8 books and 51 research papers to her credit; out of which 22 research papers are published in Emerald, Sage, Inderscience and ABDC listed journals. Dr. Amarjeet is associated with UGC EDUSAT program for higher learning and delivers live lectures on Television at Doorsarshan VYAS Channel for Higher Education in India and has more than 120 videos available on YouTube. She holds vast administrative experience as Director and Dean while working with prestigious business schools and regularly conducts training programs for corporate clients.

\section{References}

Adams, S. J., Lea, R. B., Harston, M. E. (1999). Implementation of serial-case pedagogy in the introductory managerial accounting course. Issues in Accounting Education Vol. 14, No. 4.

Aithal, P. S., \& Aithal, Shubhrajyotsna (2020). Analysis of the Indian National Education Policy 2020 towards Achieving its Objectives. International Journal of Management, Technology, and Social Sciences (IJMTS), 5(2), 19-41. DOI: http://doi.org/10.5281/zenodo.3988767.

Alavi, M. (1994). Computer-mediated Collaborative Learning: An Empirical Evaluation. MIS Quarterly. 1994, June, 159-174 (quoted by Beets and Lobingler, 2001)

Barber, M. \& Mourshed, M. (2007). How the World's Best Education Systems Come Out on Top, London \& New York, McKinsey

Barthold, Lauren Swayne (2016). A Hermeneutic Approach to Gender and Other Social Identities. New York: Palgrave Macmillan.

Costa, C., Paula, A., Pedroso, M., \& Ferreira, M. (2015). Pedagogical Interaction and Learning Performance as Determinants of Academic Achievement. Procedia Social and Behavioral Sciences, 171, 874-881. http://doi.org/10.1016/j.sbspro.2015.01.203

Entz, Susan (2007). Why Pedagogy Matters: The Importance of Teaching in a StandardsBased Environment. Forum on Public Policy Online, v2007 n2 Spr 2007

Gandhi, Mahatma (2009). The Bhagavad Gita According to Gandhi. North Atlantic Books Goyandaka, J. (2010). Srimad Bhagavad Gita (English Commentary). Kolkata: Gita Press, Gorakhpur.

Hermeneutics, First published Wed Dec 9, 2020, retrieved on May 15th 2021. https:/plato.stanford.edu/entries/hermeneutics/

New Education Policy 2021 School: NEP 2020 Implementation Date. (2021). Retrieved 13 July 2021, from https://www.policeresults.com/new-education-policy/ 
Jensen, R. E., and Sandlin, P. K., (1992). Why do it? Advantages and Dangers of New Waves of Computer-aided Teaching/Instruction. Journal of Accounting Education 10(1): 39-60.

Malhotra A. K. \& Verma P. (2021). Implementation of National Education Policy-2020: Theoretical Model on Pedagogy, University News-A Journal by AIU, Vol 59, No 7, PP 64-69.

Maudgil Asha (2017). Relevance of Bhagwad Gita in the 21st Century: a Perspective from Pedagogy. Sucharitha: a journal of philosophy \& religion, ISSN : 2319-4235, volume 5, issue 1, January, pp 1-10.

Mynbayeva, A. \& Sadvakassova, Z. \& Akshalova, B. (2018). Pedagogy of the Twenty-First Century: Innovative Teaching Methods. 10.5772/intechopen.72341

Nandini (2020). New Education Policy Highlights: School and Higher Education to See Major Changes. Hindustan Times, Available from: https://www.hindustantimes.com/education/new-education-policy-2020-liveupdates-important-takeaways/story-yYm1QaeNyFW4uTTU3g9bJO.html. [Last accessed on Jan $24^{\text {th }}$ 2021].

New Education Policy, Government of India, Ministry of Human Resource Development; 2020. Available from: https://www.mhrd.gov.in/nep-new. https://www.education.gov.in/sites/upload files/mhrd/files/NEP Final English 0.pdf [retrieved on 24th January, 2021]

Paolini, A. (2015). Enhancing Teaching Effectiveness and Student Learning Outcomes. Journal of Effective Teaching, v15 n1 p20-33

Panditrao M. M., Panditrao (2020). National Education Policy 2020: What is in it for a Student, a Parent, a Teacher, or us, as a Higher Education Institution/University? Adesh Univ J Med Sci Res ; 2(2):70-9

Reber, J. S., Downs, S. D., \& Peterson Nelson, J. A. (2017). Effects of Three Pedagogies on Learning Outcomes in a Psychology of Gender Lecture: A Quasi-Experimental Study. Teaching of Psychology, 44(2), 134144. https://doi.org/10.1177/009862831769261

Sharma N. et. al. (2017). Linking Professionalism to Nishkam Karma and how it can Reshape the World We Live in. IOSR Journal of Business and Management (IOSRJBM, e-ISSN: 2278-487X, p-ISSN: 2319-7668, PP 50-53

Sahni Nivedita \& Rao Sumita K (2017). Identifying Elements of the Code of Professional Ethics for Teachers in The Bhagavad Gita: A Hermeneutic Study. European Journal of Education Studies. ISSN: 2501 - 1111, Vol 3, Issue 7, PP 716-729

Singh S. (2016). Pedagogy of Value Education in the Light of Teachings of the Bhagavad Gita. Educational Quest: An Int. J. of Education and Applied Social Sciences Vol 7, Issue 3, DOI: 10.5958/2230-7311.2016.00052.0

Vermani S. (2018). Life Lessons from Bhagwad Gita. International Journal of Basic and Applied Research, www.pragatipublication.com ISSN 2249-3352 (P) 2278-0505 (E), July, Volume 8, Number 7, PP 598-607. 
Vilppu, H. et al (2019). The Effect of Short Online Pedagogical Training on University Teachers. Interpretations of Teaching Learning Situations. SCI 47, PP 679-709

Vlachopoulos, D., Makri, A. (2017). The Effect of Games and Simulations on Higher Education: A Systematic Literature Review. International Journal of Education and Technology in Higher Education, 14, 22 . https://doi.org/10.1186/s41239-017$\underline{0062-1}$

Whelan, F. (2009). Lessons learned: How Good Policies Produce Better Schools. London, Fenton

White, L. F. (1998). Motivating Students to Become more Responsible for Learning. College Student Journal Vol. 32, No. 21. 
Gita Manishi Swami Gyananand Maharaj, Markanday Ahuja, Amarjeet Kaur Malhotra

IMPLEMENTATION OF NATIONAL EDUCATION POLICY (NEP) 2020 OF INDIA: A PERSPECTIVE ON PEDAGOGY FROM BHAGWAD GITA

Creative Commons licensing terms

Author(s) will retain the copyright of their published articles agreeing that a Creative Commons Attribution 4.0 International License (CC BY 4.0) terms will be applied to their work. Under the terms of this license, no permission is required from the author(s) or publisher for members of the community to copy, distribute, transmit or adapt the article content, providing a proper, prominent and unambiguous attribution to the authors in a manner that makes clear that the materials are being reused under permission of a Creative Commons License. Views, opinions and conclusions expressed in this research article are views, opinions and conclusions of the author(s). Open Access Publishing Group and European Journal of Education Studies shall not be responsible or answerable for any loss, damage or liability caused in relation to/arising out of conflicts of interest, copyright violations and inappropriate or inaccurate use of any kind content related or integrated into the research work. All the published works are meeting the Open Access Publishing requirements and can be freely accessed, shared, modified, distributed and used in educational, commercial and non-commercial purposes under a Creative Commons Attribution 4.0 International License (CC BY 4.0). 